\title{
ABOUT EXPERIENCES GAINED IN SOME STUDENTS' WORKSHOPS
}

\author{
Maria Dorina PAȘCA \\ University of Medicine and Farmacy Tîrgu-Mureș, Romania \\ mdpasca@yahoo.com
}

\begin{abstract}
On the occasion of some workshops in which students from medicine participate, they come in contact with different source of information, enrich their experience and establish new relations with their colleagues, into a specific educational context. Otherwise, by the themes approached during the workshops and by the horizon of knowledge, the students acquire a set of information designed to meet their need of personal, social and professional identity. Describing two workshops focused on communication in psychotherapy and personal development, this paper presents the educational strategies and outcomes that finally lead to very productive students-trainers relationships.
\end{abstract}

\section{Keywords: student interaction, workshop, attitude, communication}

According to DEX [1], the word workshop means: working group or studio, which indicates that, default, we are dealing with a group of people who adapt to certain conditions and methodological requirements, so the theme or topic proposed to be completed in due time.

Thus the workshop acquires a high quality of the educational strategy, which ranks it in the category of non-formal activities, giving it the identity and specificity of the moment. The participants identify, debate an item or work on him, in a concentrate manner (In a limited time). The object of interest can rose from a group or from individuals, at a certain time.

In this context, the workshop has a rich diversity of approaches, both in terms of:

- theme;

- duration;

- ambient/location;

- trainers;

- target group;

- number of participants;
- methodology.

So we can answer the equation of knowledge from:

- What theme could we choose? (Information)

- Who choose the theme? (Owner)

- Who conduct and develop the theme? (Trainers)

- When the workshop takes place? (In time)

- Where is the workshop done? (The location)

- How the workshop is conducted? (The educational strategy)

- Why it is necessary to support this workshop?

Both intrinsic and extrinsic motivation occurs, which causes not only the decision making regarding the above questions, but also the attitude. These imply social behaviors designed to determine a new participants' approach to the concept and the value of their future identity.

To support and conduct a workshop, the following are needed [2]: courage, 
professionalism and responsibility, the feedback link between the emitter (E) and receiver $(\mathrm{R})$ that acquires new meanings of education. Thus, the student expresses differently, empower, communicate, relate and, why not, take a decision, becoming highly significant by itself.

Progressively, "what" becomes "who", because we focus on a new identity. Because the trainer (teacher) manifests itself in a new conceptual context, the interest, curiosity, creativity and even personality traits define him as a flexible and professional partner on discussion.

Used in conditions of incontestable professional value, the workshop is an example of the success of a new educational approach. We believe that its implementation at the scientific event of students is the consequence not only of the scientific competence and value, but especially of human values.

A good habit has already established at the scientific events of students, organized and conducted by the University of Medicine and Pharmacy from Târgu Mureş. Workshops are always present, in almost all preclinical and clinical disciplines, as ways of students-trainers interaction and beyond that, aiming in fact, a new educational strategy, involving and implementing new vision of the academic actors.

Thus, at the theoretical approach mentioned above, "the casuistry" in fact, comes to give the endorsement of success. The conditions are these: theme, message, information, the group and the trainer itself to arouse interest, to be eager to know more, under various aspects, methods and processes, more or less didactic.

The theme, in our case, was focused on broad outlines the knowledge of what is the psychotherapy. In particular, those was divided on combined arts therapists, occupational therapies and strategic insights on the role and place of the questions in doctor-patient communication (the power of the word in the same relationships), and finally, not forgetting the important moment of self-awareness and self-evaluation.

Under such auspices, they were held workshops which were:

- over 2 hours;

- $\quad$ target groups: medical students;

- date: related context;

- room - university auditoriums;

- time - especially one when the interest and curiosity are highest.

We believe that, in terms of methodology, it is welcomed to present the landmarks that conduct the workshops themselves. It should be noted that all supported activities had a well-defined internal structure, starting from:

a) started exercises - "ice breaking" type;

b) gradually introduction into the topic properly game and exercise being presented and accepted;

c) it is welcome the presence of a few basic elements that relate the theory to the theme itself - purpose, objectives, methods, specific identity;

d) practical activities - aimed at achieving the items proposed by the direct involvement of participants (students);

e) closing activities - by presenting / exposing the works / products made during the workshop; individual and group assessments; feedback achievement; noting that the proposed have been achieved;

f) final exercise - handshakes, greetings, hugs type.

Our desire is not to standardize the development of workshops, but to leave open the manner of their deployment, the goals being the ones that must reach the purpose and the success for both students and moderator. The experience we have accumulated so far gives us confidence that we can share the acquired results during the conducting and organizing workshops at scientific events of UMF Târgu Mureş, having as a starting point the knowledge of medical psychology, communication and doctor-patient relationship and factors of psychotherapies.

So we move to present in a structured 
form, a summary of two successful workshops:

\section{Workshop 1: The specific questions in the communication with patients}

Knowing that the question itself has its defined place and role in the patient history and beyond, we tried to bring it to the forefront of the communication and the networking with the patient, giving up its conventional addressing forms and bringing to the fore "listen with the heart" and "getting involved". We started from the formula HEDHE, developed by D. ServanSchreiber [3], where "daily routine turns into a magical moment". The author starts from little things that caused some problemsituations and try to resolve them in the context of open road communication and the close relationship between doctor and patient.

Decoded, HEDHE requires a set of five questions, structured as follows:

a) What happened? (The patient tells what caused the trouble and thus basically is exceeded the painful moment.)

b) What emotion you felt? (Patient relives the moment; it feels it is important to be close to us.)

c) What do you found to be the most difficult? (This question is magical, because it helps the patient to focus on the events that have created his state, it being often the psychological nature, generally affectivevolitional.)

d) Can you handle? (Helps the patient to proceed to find its own resource to solve the problem-situation, with the support of our assistance, but without us to solve his problem.)

e) Empathy (We share his feelings, ensuring that we are close to him, giving him certainty that we listened, and he is no longer alone.)

A wide range of patients can benefit to this technique to address the questions, considered to be atypical. Age is not a barrier; only the approach makes the difference and is a condition for good results.

The theme needed the directly involvement of the future physician in the communication and the relationship with the patient, starting to the trivial question.

The objectives were:

- Development of positive thinking;

- Addressing the topic from a new perspective;

- Practicing verbal and non-verbal communication;

- Development of creativity.

As working methods, we used: conversation, explanation, exercise and demonstration. In the activity, the practical approach has been eloquent, so it could be demonstrate that "small things" can trigger imbalances, disturbances and discomfort, making the medical attitudes in the communication and relation with the patient to be different. The participants could give value to the exercises, leading to resolve, or at least to detect the existing problem, making a structured and integrated approach in the anamnesis.

\section{Workshop 2: Self-knowledge and self evaluation}

For our evolution as individuals in the community of reference, M.D. Paşca and T. Tia [4] consider that the knowledge of our own values is very important. This may be considered "de facto" an element of personality, going from self-knowledge, self-confidence, self esteem, and not least, self-image. In this context, the paradigm is based on "what we are" and "who we are", the structural determinations being obvious and reported, why not, in time and space.

The theme aims to address the element of self-knowledge and selfevaluation as tools of the future opportunities of medical students and their identity.

The objectives were:

- Awareness of the element of knowledge;

- Awareness of the element of selfknowledge; 
- Recognition of own human values;

- Implementation of a valuable lifestyle.

As workshop logical flow, they were considered several ideas of V. Levi [5] about self-knowledge, namely:

- You can not change yourself to the desired direction without permanently study you;

- You can not study you without trying to change you;

- You can not study you without study others in the same time;

- You can not study the human being passive towards him.

- You can really know someone only helping him.

- You can study you or others only in activity and in the communication process.

Human knowledge and selfknowledge mainly are inexhaustible because man is an "open system", which changes constantly and unpredictably. More than any other being, man does not "is" it "become".

The whole approach was an attitudinal one, so that the quality and human value will lead to a progressive personal and social identity.

We considered that the presentation of these two workshops as "good practices" responded to the requirements of students supported and demonstrate that this way of working can and must become viable, flexible and arouse a great interest. The aim can be actually translated as: attitude, psychosocial behavior, an approach that gives the opportunity of solving cases in favor of the two academic actors: student and teacher.

\section{References}

[1] ***DEX, Ed. Academiei, București, 1975.

[2] Pașca M.D., Comunicarea în relaţia medic-pacient, Ed. University Press, Târgu Mureş, 2012.

[3] Pașca M. D., Tia T., Psihologie pastorală, vol. II, Ed. Reîntregirea, Alba Iulia, 2009.

[4] Servan-Schreiber D., Vindecă stresul, anxietatea şi depresia fără medicamente şi fără psihanaliză, Ed. Elena Francisc, Bucureşti, 2007.

[5] Levi V., Noi și eu, Ed. Didactică și Pedagogică, București, 1978. 